\title{
O batuque do Rio Grande do Sul representado em dois contos, de Maria Helena Vargas da Silveira (1940-2009)
}

Dênis Moura de Quadros denisdpbg10@gmail.com Universidade Federal do Rio Grande Rio Grande, Rio Grande do Sul, Brasil.

\begin{abstract}
RESUMO
São diversas as formas de resistência negra no Brasil. Cada região recebera escravos de diversas partes da África concebendo e desenvolvendo as práticas religiosas de maneiras distintas. O mesmo ocorre no Rio Grande do Sul em que não há a presença de Terreiros de Candomblé, mas sim de Batuque, uma religião de matriz africana específica da região sul estendendo-se ao Uruguai. Pouco conhecida e divulgada, a religião afro-gaúcha carece de estudos teóricos, ao que nos propomos nesse artigo, partindo do trabalho antropológico basilar (CORRÊA, 2016) e de outros que partem da vivência diária no Terreiro (FERREIRA, 2008; OXALÁ, 2009; SILVA, 2016; OXALÁ, 2017). Além disso, a partir da Literatura Afrofeminina (SANTIAGO, 2012), analisaremos dois contos da autora negra gaúcha Maria Helena Vargas da Silveira (1940-2009): "Jogo de búzios", de Odara: Fantasia e realidade (1993), e "Tia Bernarda de Ogum", de Tipuana (1997), em que o Batuque é central para o desenvolvimento das narrativas que recuperam a tradição afrodiaspórico gaúcha.
\end{abstract}

PALAVRAS-CHAVE: Batuque. Literatura afrofeminina. Helena do Sul. 


\section{CONSIDERAÇÕES INICIAIS}

O A cultura e, por consequência, a religião de matriz africana desenvolvem-se no Atlântico negro (GILROY, 2001) de inúmeras e diversas formas. No Brasil, as duas configurações mais conhecidas, talvez, sejam as Congadas na região sudeste, sobretudo em Minas Gerais, e o Candomblé, pulverizado no Brasil e concentrado na Bahia. Contudo, no estado brasileiro considerado hegemonicamente branco de origem europeia (primeiramente portuguesa e espanhola e, posterior a 1824 italiana e alemã), as manifestações culturais e religiosas desenvolvem-se de outra forma. A religião de matriz africana no estado gaúcho é o Batuque que, por si, modifica-se de acordo com a Nação do Terreiro, ou seja, da raiz religiosa seguida ou, como chamam no Batuque, da bacia religiosa. As variações das formas religiosas, cada dia mais homogêneas, dividem-se em cinco grandes grupos, havendo outros aglutinados com o tempo em alguma ou outra Nação, eles são: Oyó, Jeje, ljexá, Nagô e Cabinda. Ainda, acerca da cultura afrodiaspórica há as congadas que acontecem no estudo gaúcho e variam de nome, estrutura e cânticos conhecidas como: "Maçambique", em Osório-RS; "Kikumbi", em Rio Pardo-RS, e "Ensaios", em Mostardas-RS, todas similares às demais congadas em seu objetivo religioso e com o casal de reis que representam, ao que se sabe, a rainha Nzinga (1583-1663) e o Rei do Congo.

Da Literatura Gaúcha temos, ainda, certa dificuldade de elencar autores negros para comporem o cânone literário gaúcho, contudo, há muitos nomes de escritoras e escritores na contemporaneidade como, por exemplo, Lilian Marques, Ana dos Santos, Fátima Regina Farias e outros nomes ligados ao ponto de cultura Sopapo Poético ${ }^{2}$. De precursor há a figura do poeta e militante Oliveira Silveira (1941-2009) que publicou, em 1962, Germinou e posteriormente outras cinco obras poéticas. Já recortando por gênero, a lista fica mais sucinta, mas há duas autoras negras: Maria Helena Vargas da Silveira (1940-2009), publicando dez obras entre romances, novelas, contos e poemas, e Zeli de Oliveira Barbosa (1941-2017) e sua única obra Ilhota: testemunho de uma vida (1993), obra publicada pela Secretária Municipal da Cultura de Porto Alegre- RS através do projeto Outras vozes e, talvez, influenciada pelo best-seller de Carolina Maria de Jesus (19141977), seu Quarto de despejo: Diário de uma favelada (1960).

O objetivo desse trabalho é, então, discutir, em um primeiro momento, as peculiaridades estruturais do Batuque, assim como suas possíveis origens, depreendendo como a religião de matriz africana foi sendo modificada agregando a cultura gaúcha e, ao mesmo tempo, preservando as cantigas em Yorubá que, logicamente, também sofrem alterações que evocam outras pesquisas. Após discutirmos essas nuances afrodiaspóricas, analisaremos os contos: "Jogo de búzio", recortado da antologia de contos Odara: Fantasia e realidade (1993), e "Tia Bernarda de Ogum", recortado da novela social Tipuana (1997), ambos da autora negra gaúcha Maria Helena Vargas da Silveira. A análise primará pela percepção de como os textos resgatam a ancestralidade negra gaúcha e evocam, a partir do $O r^{1}{ }^{1}$, os Orixás, ancestrais míticos segundo o antropólogo Fábio Leite (2008), e demais ancestrais históricos.

Para tanto, nos servem como arcabouço teórico o primeiro trabalho acadêmico brasileiro tendo como objeto de pesquisa a religiosidade afrodiaspórica no Rio Grande do Sul, a obra Batuque do Rio Grande do Sul: Antropologia de uma religião afro-rio-grandense (2016) de Norton Corrêa; ainda, os escritos que partem 
de dentro dos Terreiros de autoria de sacerdotes também nos servem como a obra do babalorixá Paulo de Xangô, Batuque: seus encantos e rituais (2016) que aprofunda, em parte, a liturgia religiosa do Batuque; Efan-deí: O livro dos batuqueiros (2017), do babalorixá Branco d'Oxalá, que traz uma visão interna da religião; e as duas obras que partem de dois babalorixás da nação Cabinda: Quem é Xangô Kamucá na Nação religiosa de Cabinda? (2008), de Paulo Tadeu Barbosa Ferreira e Africanismo: Culto sem segredos (2009), de Pai Ronei de Oxalá.

Por se tratar de uma autora pouco conhecida na Academia e, cujas obras carecem de pesquisa, adotaremos o conceito de Literatura Afrofeminina cunhado por Ana Rita Santiago (2012) como enegrecedor para a análise literária dos contos de Maria Helena Vargas da Silveira ou Helena do Sul, epíteto que a autora assume tardiamente. Percebendo, ainda, como a voz narrativa utiliza-se da memória, buscada em sua infância, para reavaliar historicamente sua cultura afrodiaspórica.

\section{O BATUQUE DO RIO GRANDE DO SUL: A RELIGIOSIDADE AFRO-GAÚCHA}

A diáspora forçada pelo processo de escravização no Brasil é respondida com a resistência cultural dos povos africanos que, em solo brasileiro, desenvolvem as práticas culturais e religiosas de forma coletiva. A matriz religiosa, tanto do Candomblé quanto do Batuque, é africana, mas cada qual recebe a influência de determinados povos, bem como desenvolvem os rituais de iniciação e de morte (Ásésé no Candomblé e Arissum no Batuque) de formas ambiguamente semelhantes e difusas. Talvez um estudo comparado das práticas religiosas ainda leve tempo para acontecer devido ao caráter heterogêneo das nações de Candomblé, como, por exemplo, o Candomblé de Angola (Banto) que cultua Inkices e o Candomblé de Ketu (Nagô) que cultua Orixás, não diferente das nações do Batuque com diferenças bem menos marcantes. Outro ponto a ser levantado é que o Candomblé e o Batuque só existem, da forma como a conhecemos, no Brasil, ou seja, em África continuam sendo cultuadas as divindades de forma diferenciada em que um pequeno grupo de Orixás é reverenciado e não um Irumalé (panteão dos Orixás) inteiro, fora que os países africanos também passaram pela colonização forçando algumas adaptações.

Diferente do Candomblé, em que encontramos uma gama de textos teóricos e obras basilares antropológicos e outros que partem das vivências dos iniciados, Babalorixás e lalorixás, o Batuque carece de estudos mais aprofundados que partam de religiosos. Não é de hoje que o acesso ao Ensino Superior tenha sido negado aos descendentes de africanos escravizados, atenuados pelas políticas públicas que instauram cotas nas universidades, mas ainda sem grandes avanços no campo acadêmico. Além disso, as tentativas de pesquisar sobre a epistemologia afrogaúcha são recebidas com resistência na Academia que, em raras vezes, permite o estudo antropológico citando pesquisas e pesquisadores, na maioria das vezes não negros e/ou europeus, do Candomblé em detrimento da epistemologia oral afrodiaspórica.

De todas as formas, iniciamos esse capítulo com a obra basilar $O$ Batuque do Rio Grande do Sul: Antropologia de uma religião afro-rio-grandense (2016), de Norton Corrêa. A obra é resultado de sua dissertação de mestrado apresentado à Universidade Federal de Porto Alegre em 1989, orientada pelo pesquisador Pedro Ari Oro que contribui, dentro da Academia, para as pesquisas acerca das religiões 
de matriz africana no Rio Grande do Sul. Norton, em sua pesquisa de campo, apreende os conhecimentos religiosos dos rituais e das festas nas casas de Mãe Ester de lemanjá (Nação Jeje-ljexá) e Mãe Moça da Oxum (Nação Oyó), ambas de Porto Alegre-RS.

Corrêa afirma que os primeiros terreiros de Batuque tenham surgido, muito provavelmente, entre as décadas de 1730 e 1750, culminando nas datas de fundação das cidades de Rio Grande (1737), e seu porto marítimo, e Pelotas (1758), região conhecida pelas charqueadas, fazendas que abatiam gado, salgavam sua carne que ficava exposta ao sol para produzir o charque exportado. Ambas as cidades são as primeiras responsáveis pelo tráfico negreiro e demarcam os maus tratos aos africanos escravizados que, em alguns casos, tinham suas peles arrancadas pela salinidade do charque (carne de gado salgada e exposta ao sol) e viviam debaixo do rigoroso inverno sulino. Ainda, há registros de escravizados advindos de outras partes do Brasil como Pernambuco e Bahia que levanta a possibilidade do Batuque ter origem no Candomblé ou mesmo no Xangô de Recife. Contudo, essa afirmação não se sustenta devido aos Orixás cultuados, ou assim concebidos, no Batuque serem de base Jeje-Nagô em que mescla e aglutina Orixás com Voduns como é o caso de Bará e Xapanã, ambos ainda cultuados como Voduns em África. O mais correto é afirmar que, assim como o Candomblé, o Batuque nasce nas senzalas através da interação das diversas etnias africanas aglutinando alguns Orixás, como é o caso de Nanã cultuada como lemanjá, por exemplo.

Das nações, iniciaremos pelo Jeje, atualmente com poucos adeptos, que se difere das outras nações pela presença dos aguidavis, baquetas usadas na percussão do tambor, o Onilu (feito de couro de cabrito dos dois lados e atado com cordas tensionadas que afinam o tambor). Antigamente, sabia-se que o Terreiro seguia a Nação Jeje pela rapidez dos toques, contudo, atualmente, a velocidade alta tem sido uma constante nas casas de Batuque. A Nação Jeje, ainda, inicia os xirês pela dança em par, feita apenas por homens ou por sacerdotes que têm Orixás masculinos assentados, em louvor à Bará Lodê. O baluarte desta Nação é a figura mítica do Príncipe Custódio (Joaquim Custódio de Almeida [1932-1935]). A nação ljexá segue os mesmos rituais da Nação Jejê e da Nação Nagô, inclusive, a entrada dos Orixás mescladas em masculinos e femininos (Bará, Ogum, Oyá, Xangô, Odé, Otim, Ossanha, Obá, Xapanã, Oxum, lemanjá e Oxalá), e tem como grande rainha da nação a Orixá Oxum. A nação Nagô também segue uma estrutura pré-fixada e encontra-se mesclada com outras nações. Já o Oyó segue outra ordem de entrada dos Orixás assemelhando-se a ordem do Candomblé de Ketu, com Orixás masculinos primeiro e depois os femininos com alguma variação (Bará, Ogum, Xapanã, Odé, Ossanha, Oxalá de Orumilaia, Oxalá Obokun, Xangô Agodô, Xangô de Ibêji, Xangô Aganju, lemanjá Nanã Buruku, Otim, demais qualidades lemanjá, Oxum, Oyá e demais qualidades de Oxalá), além disso, diferente das demais nações, os Okutás (pedras em formatos específicos que carregam o axé do Orixá a que fazem correspondência) são plantados. Por fim, e não menos importante, temos a nação de Cabinda em que constam as maiores rupturas como, por exemplo, o culto à Leba (um Vodum), Zina e, sobretudo, Xangô Kamucá. Todos os rituais de Cabinda iniciam pelo Balê (espaço onde são cultuados os ancestrais históricos ou Eguns). A entrada dos Orixás no Xirê segue a estrutura Jeje-Nagô

Acerca dos Orixás cultuados e a ordem das rezas (cânticos rituais) no dois grupos assimétricos: Orixás do dendê e Orixás do mel ou de praia. $O$ primeiro 
grupo é constituído dos Orixás que levam em suas frentes (oferendas) dendê como elemento principal: Bará, Ogum, Oyá, Xangô, Odé, Otim, Ossanha, Obá e Xapanã. Do outro grupo, os Orixás que levam mel em suas frentes e que são considerados de misericórdia e são: Oxum, lemanjá e Oxalá. A nação Jeje-nagô, diferente das outras, cultua uma qualidade de Bará, o Bará Ajelú, como Orixá de praia, pois esse Bará faz a ligação Ayê-Órum com os Orixás de praia levando mel em suas oferendas. Já a Nação Cabinda cultua, pelo menos, dois Orixás que rompem com a tradição das demais nações: Leba, um Vodum, que faz a ligação com os ancestrais recebendo oferendas no cemitério, podendo ser confundido com um Bará Lodê, e Xangô Kamucá, um caminho de Xangô relacionado ao cemitério. Sobre Kamucá, Paulo Tadeu Barbosa Ferreira (2008) afirma ser o Orixá Rei da Nação Cabinda que não mais poderá ser assentado na cabeça de alguém, pois assume essa função dentro da nação. Esse Orixá, primeiro e único na leitura de Ferreira, é o Orixá do baluarte Waldemar Antonio dos Santos que iniciou a nação e, dessa forma, não há nenhum Terreiro de Cabinda que tenha Waldemar de Xangô Kamucá em sua árvore familiar religiosa.

Pai Ronei de Oxalá (2009) descreve as etapas que tornam um iniciado sacerdote, ou na linguagem batuqueira, torna-o um pronto. $O$ primeiro ritual constitui-se do amaci em que o Ori do iniciado será lavado com ervas que variam de acordo com o Orixá descoberto pelo Ifá, jogo de búzios, bem como seus adjuntós, Orixás que acompanham o iniciado e que são representados no ara (corpo). Esse primeiro ritual marca o início da vida religiosa do iniciado em que ele é instruído a seguir o preceito religioso: ficando alguns dias sem poder ingerir bebidas alcoólicas, fazer sexo, cortar os cabelos e evitar, desde então, alimentarse de arroz com galinha, arroz com linguiça, arroz com couve, por serem comidas rituais no culto aos ancestrais. O segundo ritual é o aribibó que conta com a sacralização de aves e repouso do iniciado no Terrreiro. Não há uma contagem de tempo específica entre o amaci e o aribibó, o tempo varia de iniciado para iniciado de acordo com os conhecimentos adquiridos dentro do Terreiro, na vivência prática dos rituais. Os dois próximos rituais contam com a sacralização de mais animais e mais tempo de recolhimento: Bori de aves e Bori de quatro pés. Diferente do Candomblé, os rituais de Bori no Batuque representam a preparação do adepto para o sacerdócio. No Bori de quatro pés são sacralizados quadrúpedes que variam de Orixá para Orixá podendo ser caprinos ou ovinos, nesse Bori são assentados os Orixás do filho no santo. Por fim, após assentar todos os Orixás é marcado um xirê em que o filho receberá os axés de Ifá (búzios) e Obé (faca), já podendo, desde então, abrir seu llê. Há também, após o Bori de quatro pés o ritual chamado "passeio" em que o batuqueiro visita determinados pontos da cidade por onde passaram seus ancestrais como, por exemplo, mercados públicos, praias e Igrejas católicas.

No Batuque, os adeptos não podem saber que se ocupam com seus Orixás, ou seja, que recebem em seus corpos os Orixás, sendo esse um segredo guardado a sete chaves e que traz consigo uma gama de histórias de loucura e morte. Esse tabu, dentro da própria ritualística segue alguns detalhes como a quebra do Orixá quando está baixando, isto é, passa por um ritual em que o Orixá toma por completo a consciência do filho e, após ser despachado, antes de subir em definitivo, fica em estado de axerê, forma mais pura do Orixá que lembram crianças. Silva (2016) discorre sobre a composição do xirê: "Iniciado o Batuque, forma-se uma roda, que girará no sentido anti-horário." (SILVA, 2016, p. 26), esse sentido representa o retorno aos ancestrais míticos que rompem com o tempo 
cronológico. Além disso, quando há sacralização de quadrúpudes é feito o ritual da balança, o Emissô Kassum, em que os prontos, de mãos dadas, dançam em círculo encerrando no alujá de Xangô, dono da balança e quem dá a aprovação dos sacrifícios.

O Babalorixá Branco de Oxalá (2017) discorre sobre inúmeros rituais e elementos ritualísticos dentro do Batuque, em uma dessas passagens descreve a forma de consultar Ifá, abrir o jogo de búzios, entregue no Batuque de aprontamento em que o pronto, agora sacerdote, recebe os búzios, a sineta (elemento do Orixá Bará) e a Imperial, guia que traz todos os Orixás:

[...] estende-se uma toalha branca (infinito) e sobre ela dispõem-se a guia imperial que é representante de todos os Orixás (Universo), duas favas que ao iniciar o jogo são entregues nas mãos do consulente, a sineta que desperta os vínculos da comunicação, uma moeda posicionada de forma central (representante do indivíduo em questão), que pode ter mais 4 dispostas a seu redor porém mais próximas da guia (fogo, água, terra e ar), geralmente 8 ou 16 búzios dispostos ao redor da moeda central como se apontando para a mesma. (OXALÁ, 2017, p. 120).

Diferente da leitura que ocorre no Candomblé, através dos 16 odús (ítãs sobre o destino e que representam um ou mais Orixás), no Batuque a leitura é feita pelo (s) Orixá (s) que "respondem" no jogo, ou seja, pela caída dos búzios próxima à Imperial. Por exemplo, quando dois búzios caem próximos ao espaço da imperial que representa Ogum (normalmente nas cores vermelha e verde), lê-se que o Orixá tem um recado ao consulente que depende, também, da forma como os búzios caem na mesa.

Por fim, Norton Corrêa (2016) consegue sintetizar o que representa o Batuque do Rio Grande do Sul para seus adeptos, pois ser batuqueiro: "[...] mais do que simplesmente praticar uma religião [...] significa revestir-se de uma identidade que compreende e expressa um etos, uma filosofia e um modo de vida específicos, que se refletem na vivência do cotidiano." (CORRÊA, 2016, p. 69), ou seja, se é batuqueiro vinte e quatro horas do dia, bem como se aprende através da vivência diária no Terreiro, assimilando as rezas, os gestos dedicados a cada Orixá, as frentes (oferendas) e suas variações, a limpeza dos animais sacralizados que serão servidos nos xirês, entre outros segredos do Batuque. Um ponto importante a ser ressaltado, ainda, são as inúmeras adaptações que demarcam o espaço gaúcho, cito duas delas: a primeira é a oferenda servida ao Orixá Ogum que consiste em um pedaço de costela assada; a segunda está na vestimenta dos batuqueiros constituída de bombachas, na maioria das vezes largas, que constituem a indumentária batuqueira. Dois elementos gaúchos que foram, com o tempo, adicionados aos Terreiros e demarcam o Batuque em relação a outras religiões de matriz africana e, até mesmo, afro-brasileiras como a Umbanda e Kimbanda, por exemplo. HELENA VARGAS DA SILVEIRA (1940-2009) 
Nascida em Pelotas- RS, em 4 de junho de 1940, forma-se no Magistério, atual Curso Normal, ainda em Pelotas- RS. Muda-se para Porto Alegre, licenciandose em Pedagogia pela UFRGS (Universidade Federal do Rio Grande do Sul). Lecionou como professora em escolas públicas de diversas cidades gaúchas, entre elas Pelotas- RS e São Lourenço do Sul- RS e Porto Alegre- RS. Foi a primeira pedagoga da rede de supermercados Carrefour e em 1999 muda-se para Brasília com a finalidade de assumir um cargo administrativo na Fundação Cultural Palmares, local que assume o epíteto de Helena do Sul. Atuou durante dois anos como consultora de projetos e planejamento da formação continuada de professores que lecionavam em áreas remanescentes quilombolas, além de ter sido consultora da UNESCO (Organização das Nações Unidas para a Educação, a Ciência e a Cultura). Helena do Sul torna-se uma Ancestral em 2009, vítima de um aneurisma cerebral. (EVARISTO, 2011)

Apesar de, ainda, haver poucos estudos acerca de sua obra, Maria Helena Vargas da Silveira publicou, em vinte anos, dez obras: É fogo! (1987), romance de formação que narra a história de Maria, desde sua infância à aposentadoria como docente; Meu nome Pessoa: Três momentos de poesia (1989), antologia de poemas; O sol de fevereiro (1991), antologia de contos que giram em torno do Beco das Pereiras; Odara: Fantasia e realidade (1993), antologia de contos em que são adicionadas palavras em Banto e em Nagô; Negrada (1995), antologia de crônicas publicadas DM Cultural, suplemento cultural do jornal Diário da Manhã de PelotasRS; Tipuana (1997), primeira novela social que traz a escola fictícia Tipuana localizada no Morro do Nenê; O encontro (2000), segunda novela social; As filhas das lavadeiras (2002), em que a autora recolhe vinte e um relatos de filhas de lavadeiras da região sul e sudeste; Os corpos e Obá contemporânea (2005), terceira e última novela social que traz ao centro o ítã de Obá3; e Rota existencial (2007), em que a autora retoma seus vinte anos de produção, recordando os lançamentos de seus livros com alguns contos e poemas inéditos.

Para tanto, o conceito de Literatura afrofeminina, cunhado por Ana Rita Santiago (2012) e utilizada por outros teóricos e teóricas que elencam como objeto de pesquisa escritas de autoria de mulheres negras, nos auxilia a compreender o fio condutor da narrativa de Maria Helena Vargas da Silveira, ou Helena do Sul, como a autora se autoidentifica. Essa escrita parte das memórias afrodiaspóricas em um processo de identificação e de busca de referenciais históricos. Logo, as narrativas são atravessadas por experiências de mulheres negras, sejam elas vivenciadas ou escutadas, que representam uma experiência coletiva. Contudo, não se quer repetir histórias de dor, de violência e de violação dos direitos básicos, mas retratá-las criticamente de forma que seja possível romper com estereótipos subalternizantes e reafirmar a negritude e a ancestralidade. Santiago (2012) afirma que: "[...] as memórias aparecem através e com as memórias do outro, ou seja, de múltiplas feições e vozes, tornando-se memórias de si/nós" (SANTIAGO, 2012, p. 27).

São essas memórias que conduzem a narrativa da autora que recupera a ancestralidade afrodiaspórico incorporando às narrativas elementos negrobrasileiros e das religiões de matriz africana, em especial, o Batuque. Odara: Fantasia e realidade (1993), a autora discorre sobre a ancestralidade negra reavaliando-a historicamente. Dessas quatorze narrativas recortei o conto "Jogo de búzios", pela presença clara do Batuque, contudo, os demais contos também discorrem sobre a cultura e a religião de matriz africana, bem como os espaços de 
resistência negra gaúcha como, por exemplo, as tribos carnavalescas: grupos organizados para pular as noites de carnaval, desfilando e encerrando a noite, normalmente, nos clubes negros.

"Jogo de búzio" é um conto que parte do Ori, não apenas o espaço físico, a cabeça ou, ainda, do Ori-odé, mas a ligação máxima do indivíduo, Ori-Inu, com seus ancestrais, mítico e histórico (LEITE, 2008). O tempo-espaço do conto não é cronológico, mas mítico e, sobretudo, espiralar a partir da Exu, ou Bará no Batuque, o Orixá mensageiro que faz as ligações Ayê-Órum. Beremim, personagem central, reflete sobre o seu viver em frente ao espelho: "Beremim olha-se no espelho e tem a sensação de dupla imagem: o rosto e a transparência dos pensamentos." (SILVEIRA, 1993, p. 31). Esse duplo representa a ligação cósmica de Beremim, mulher negra, com seus ancestrais e, sobretudo, com seu Orixá. Permeada de pensamentos que lhe tomam por completa vai buscar a orientação de Kalefá de Ogum, babalorixá pronto no Batuque.

A autora, ao descrever Kalefá de Ogum, tece duras críticas à deturpação do Batuque e outras religiões de matriz africana em que a sabedoria ancestral é vendida, tornando seus sacerdotes, na maioria das vezes, esnobes em seus templos religiosos com capas de ouro e os bolsos forrados de dólares, esquecendo em grande parte a ancestralidade. "Kalefá de Ogum é o babalaô ideal, guardião da pureza das tradições africanas" (SILVEIRA, 1993, p. 31), Vestido com um abadá branco, o babalaô entra no quarto de santo, espaço sagrado onde são guardados os assentamentos dos Orixás, bem como os Boris dos filhos de santo ainda não prontos para despertar as forças ancestrais assentadas. Esse espaço, também chamado de peji pela atual influência com o Candomblé, é uma marca do Batuque, em que na porta do quarto de santo Kelfá de Ogum toca sua sineta para despertar os Orixás pedindo licença para que a mesa de jogo de búzios seja aberta, ou seja, para que Ifá seja consultado. A autora descreve, então, o ritual de abertura dessa mesa:

Estende sobre a mesa a sua Guia Imperial em círculo, colocando no interior quatro moedas de tamanho médio, uma grande e quatro caramujos. Retira do axé-igbá, dezesseis búzios e segura-os nas mãos, apontando-os para o chão e para o alto, tocando-as na testa por três vezes. (SILVEIRA, 1993, p. 32).

As semelhanças entre o ritual de abertura do oráculo de Ifá descrito pelo babalorixá Branco de Oxalá (2017) com o ritual descrito no conto de Maria Helena (1993) não se encerram nos elementos descritos por ambos, mas também nas respostas das jogadas e caídas dos búzios. Kalefá de Ogum joga três vezes os búzios que, conforme a resposta, vão desvelando segredos e caminhos possíveis do Ori de Beremim.

A primeira jogada é respondida pelo silêncio, nenhum Orixá responde, esse fato se ocorresse na realidade teria fechado o oráculo podendo o consulente estar próxima de sua morte ou que tenha ingerido bebida alcoólica ou mesmo acabara de fazer sexo, mas Kalefá de Ogum explica a caída assombrosa do Ifá: "Os Orixás são afros e estão na tua cabeça" (SILVEIRA, 1993, p. 32) e o Ori de Beremim está repleto de ancestrais demandando proteção e revolta. Esses ancestrais, no Ori de Beremim, evocam a reflexão acerca da representatividade negra, ou a falta dela, na mídia que permite o protagonismo negro apenas no carnaval, ponto máximo da 
falsa democracia racial. Kelefá também discute com Beremim acerca do corpo sexualizado das mulheres negras através da figura da mulata, corpo tido como permitido na lógica machista-patriarcal-heterenormativa, mas rejeitado nos comerciais de roupas íntimas femininas ignorando, na época, o poder aquisitivo dessas mulheres em detrimento ao "padrão" de beleza feminino. A sexualização do corpo feminino negro ainda ocorre, tanto na mídia como na literatura brasileira canônica, em especial, as mulatas representadas por Jorge Amado (1912-2001), contudo o capitalismo, em suas propagandas publicitárias, já adiciona essas consumidoras com mais naturalidade. Beremim afirma: "Ainda não apostam no negro para uma imagem positiva." (SILVEIRA, 1993, p. 33). A autora vai, então, enumerando as opressões racistas que concebem os negros como preguiçosos, marginais, libidinosos e frutos de desconfiança.

Na segunda caída do jogo de búzios, os Orixás Exu/Bará e lansã quem respondem destacando a raiva e a loucura do Orí de Beremim evocados pelo racismo. Kalefá explica essa loucura que em nada tem haver com aquela do senso comum que demarca a falta de racionalidade: "Teu espírito arteiro e irreverente fixa os ideais de lutar pela tua etnia. Gostas de interceder pelos negros toda vez que os agridem" (SILVEIRA, 1993, p. 34). Beremim concorda acerca de sua ira contra todos aqueles que discriminam os outros por inúmeros motivos, entre o racismo, o sexismo, a homofobia e outras discriminações presentes na sociedade brasileira. Beremim vê o mundo de forma heterogênea compreendendo e aceitando as diferenças, pois o que torna cada um especial é, exatamente, essas diferenças. A loucura, talvez, encontre-se na impossibilidade de mudar essa realidade, mas Beremim tem coragem, não é à toa que a Orixá das revoluções, lansã, sopre em seu Orí e responda na mesa de jogo de búzios de Kalefá.

Na terceira e última jogada ocorre o oposto da primeira: "Todos os Orixás respondem. Há uma energia mágica e fantástica em tua vida." (SILVEIRA, 1993, p. 35). lemanjá, a mãe de todas as cabeças na visão batuqueira, responde à Beremim que busque a companhia, a coletividade, pois é na solidão dos embates que os conflitos são agravados. Ainda, essa coletividade como forma de resistência é ratificada pelo fato de Beremim fortalecer-se no povo negro em um processo duplo em que ela também é fortalecida. $O$ conto, então, é encerrado com o retorno ao tempo-espaço cronológico em que Beremim encontra-se frente ao espelho, elemento mítico e místico das Orixás lemanjá e Oxum com seus abebês (lequeespelho). Beremim afirma: "Kalefá de Ogum, tu não existe! És o reflexo de minha consciência, extrapolando a realidade. Agô !!!" (SILVEIRA, 1993, p. 36). Kalefá, muito provavelmente, é um ancestral de Beremim que, através de seu Orí, orienta e organiza seus pensamentos desconexos. Certamente, Beremim reencontra-se após os encaminhamentos de Ifá, seu Orí lhe conduz e reorganiza seus pensamentos de forma reflexiva, ao mesmo tempo em que faz o leitor refletir.

Já o conto "Tia Bernarda de Ogum" é parte da novela social Tipuana (1997), em que Maria Helena Vargas da Silveira narra o nascimento da escola que nomeia a novela, bem como do Morro do Nenê constituído de trabalhadores das várias partes do Rio Grande do Sul em busca de melhores condições de vida. Esses moradores são, majoritariamente, negros e vão, aos poucos, tendo suas histórias contadas na obra através do diálogo com a diretora Isolda. O conto, ainda, faz parte de um grupo de três contos que evocam o banzo, dor negra engendrada pela rememora o bacião de lata em que tomava banho quando criança, em um conto, 
e a jacuba, sua principal alimentação quando criança, uma mistura de café com farinha de mandioca em outro conto encerrando pela imagem de Tia Bernarda de axó (vestimenta ritual do Batuque).

Assim como os demais contos, em "Tia Bernarda de Ogum" há um retorno às memórias de infância em que, brincando de recortar revistas velhas, a voz narrativa é desperta pelo pai que entra em casa e faz o convite: "-Venham ver a tia Bernarda, fantasiada de São Jorge..." (SILVEIRA, 1997, p. 41), referência que faz ao sincretismo religioso do Orixá Ogum no Rio Grande do Sul. Ainda, São Jorge é, talvez, o santo católico escolhido com mais frequência no sincretismo religioso em que, dependendo da região, é sincretizado com Oxóssi e, ainda, com Xangô. A narração segue com a imagem de Tia Bernarda ocupada com seu Orixá:

Estava no pátio, calçando botas alvíssimas, vestindo bombacha vermelha, túnica verde, capacete prateado na cabeça micoca e trazia uma espada brilhante atravessadas na cintura. Fazia reverências defronte uma casinha pintada de vermelho, rodopiando. Alçou a espada para o ar e entrou em casa, dançando, guerreando com o vácuo da noite. (SILVEIRA, 1997, p. 41).

Outra marca do Batuque são as casas de madeira, menores que os Terreiros, pintadas de vermelha e que guardam os assentamentos dos Orixás de rua que, variando de Nação para Nação, normalmente são Bará Lodê, Ogum Avagã e Oyá Timboá. Esses Orixás são responsáveis pela segurança dos Terreiros e, na narrativa, são descritas rapidamente rememorando uma marca negra no estado gaúcho. Ainda, quando chegam e quando partem os adeptos são obrigados a cumprimentar os Orixás batendo na porta dessa casa que é aberta apenas em dias de xirê. Outro elemento específico do Batuque é o uso de bombachas, normalmente na cor do Orixá, diferente das calças de algodão ou de renda que, atualmente, tem enchido os salões de Batuque na influência com o Candomblé.

Reforçando o sincretismo religioso que organiza o calendário religioso da maioria dos Terreiros, a voz narrativa rememora que todo dia 23 de abril, dia de São Jorge, a lembrança infantil em que Tia Bernarda a acomete e que lhe faz ficar: "Com saudades daquela preta velha no seu axó bem primitivo, peço a bênção para o santo." (SILVEIRA, 1997, p. 42). A lembrança do Batuque, ainda, retoma a festa coletiva que envolve toda a comunidade em que o Terreiro se localiza. Além disso, as crianças são muito bem-vindas nos Terreiros e fundamentais nas mesas de Ibêji, ritual do Batuque em que as crianças são servidas de canja e de doces e que, na visão batuqueira, afastam a morte. Essa mesa, apesar de se referenciar aos Ibêjis, Orixás gêmeos, retoma não esses Orixás, como no Candomblé, mas duas passagens infantis dos Orixás Xangô, Aganju de Ibêji, e Oxum, Pandá de Ibêji, ambos filhos de Xangô e Oyá.

\section{CONSIDERAÇÕES FINAIS}

A cultura e a religião de matriz africana resistiram de diferentes formas. As várias tribos, muitas inimigas, que aportaram no Brasil tiveram que adaptar suas práticas religiosas escondidas nas senzalas e, em muitas vezes, confundidas entre as imagens de santos católicos. Falar em sincretismo, hoje em dia, nos parece descabido, visto que já não é mais crime a prática religiosa e cultural afrodiaspórica, contudo é também descabido comparar as formas religiosas afro- 
brasileiras com as práticas africanas nas regiões também colonizadas e, logo, sofrendo adaptações para resistir. A busca de uma pureza, cada dia mais explorada, desloca o eixo da ancestralidade e dos saberes passados oralmente dentro dos Terreiros para uma modernidade, argumento de muitos que buscam as mudanças das práticas batuqueiras, que tem rompido com a tradição batuqueira deixando-a mais parecida ao Candomblé.

A bombacha, vestimenta típica do Batuque, tem sido deixada de lado pelas roupas tecidas em algodão ou renda, advindas de Guiné-Bissau, Angola, Nigéria e outros países africanos, em uma imitação clara ao Candomblé e trazidas por esses africanos que imigram para o Brasil. A sineta, instrumento de Bará, que acorda as energias ancestrais tem sido substituída pelo adjá, instrumento comum no candomblé com som mais oco e bem menos estridente. Talvez, a próxima mudança ocorra nas frentes, oferendas aos Orixás, substituindo a costela assada de Ogum pelo cará (Dioscorea bulbifera) como ocorre nas oferendas ao Orixá no Candomblé. A modernidade tem servido de argumento para que a tradição seja rompida, por outro lado, as modificações já ocorriam antigamente em que as Nações mesclam-se não havendo, pelo menos majoritariamente, nenhuma casa pura, ou seja, que cultua apenas os preceitos litúrgicos de uma Nação, nem mesmo a Cabinda que recebe iniciados em outras nações. Assim, só o tempo dirá se tais mudanças serão, a meu ver, problemáticas ou benéficas ou, ainda, naturais.

A Literatura Gaúcha, apesar de o cânone cristalizado ser idêntico ao cânone literário nacional- homens brancos, de classe média e média alta com alguma formação acadêmica- tem sido reescrita, abalando suas estruturas através de estudos engajados da História da Literatura. O sarau Sopapo Poético é apenas o começo para uma extensa lista de obras enegrecidas, do reconhecimento da cultura africana no estado e da reavaliação histórica rompendo com as marcas dolorosas deixadas pelas charqueadas e pela morte da tropa de lanceiros negros em Porongos (14 de novembro de 1844) que, de acordo com o historiador gaúcho Moacyr Flores (2004), dizimou a tropa de homens negros logo após terem retiradas suas armas, traídos pelos revoltosos farroupilhas.

Maria Helena Vargas da Silveira (1940-2009) já aparece como precursora. Responsável pela produção de dez obras literárias que merecem a atenção da crítica literária e, sobretudo, da História da Literatura legitimando-as. A cultura afro-gaúcha é, em parte, o fio mnemônico que conduz suas narrativas e poemas que, como Exu, movimenta-se em espiral retornando-se e mesclando-se à sua memória. O resultado desse movimento e dessa mescla rompe com a tênue linha entre realidade e ficção. Além disso, suas memórias também são memórias de outrem, negras e negros discriminados pelo racismo. Nos contos aqui recortados percebemos o cuidado na descrição dos rituais, sem a preocupação em explicá-los, mas sendo minuciosa nos gestos. Gestos esses que se repetem, sem muitas adaptações, nos xirês em que os batuqueiros movimentam as mãos como se tivessem uma chave na reza de Bará; as mãos espalmadas e cortando o ar como se fosse a própria mão uma espada na reza de Ogum e de Oyá, entre outros.

Beremim e Kalefá de Ogum partem do Orí, o topo da cabeça que marca a ligação do iniciado com seu Orixá, o Ayê do Órum, consultando a ancestralidade mítica que respondem através dos caramujos, búzios, na caída da Guia Imperial que carrega o axé de cada Orixá que repousam no quarto de santo em suas bacias e, sobretudo, vibrando em seus okutás, pedras basálticas de diferentes formas que representam, cada uma, um Orixá. Tia Bernarda de Ogum, de bombachas, 
capacete e espada gira na frente da casa de Bará Lodê, pedindo a segurança para a noite do Batuque. Por fim, Ogum, o Orixá das guerras, da agricultura, das ferramentas e, também, da tecnologia nos permite espaço para a discussão do Batuque, pouco falado, pouco pesquisado, mas que resiste no estado considerado hegemonicamente branco. 


\title{
The Batuque of Rio Grande do Sul represented in two short stories by Maria Helena Vargas da Silveira (1940-2009)
}

\begin{abstract}
There are several forms of black resistance in Brazil. Each region that had received slaves from various parts of Africa conceived and developed religious practices in different ways. The same occurs in Rio Grande do Sul where there is no presence of Terreiros de Candomblé, but Batuque, a religion of African origin specific to the southern region extending to Uruguay. Little known and disseminated, the Afro-Gaucho religion lacks theoretical studies, which we propose in this article based on the basic anthropological work (CORRÊA, 2016) and others that start from the daily experience in the Terreiro (FERREIRA, 2008; OXALÁ, 2009; SILVA, 2016; OXALÁ, 2017). In addition, from afrofeminine literature (SANTIAGO, 2012), we will analyze two short stories by the black author Maria Helena Vargas da Silveira (1940-2009): "Jogo de búzio", by Odara: Fantasia e realidade (1993), and "Tia Bernarda de Ogum", by Tipuana (1997), in which Batuque is central to the development of narratives that recover the Afrodiaporic tradition of Rio Grande do Sul.
\end{abstract}

KEYWORDS: Batuque. Afrofeminine literature. Helena do Sul. 


\section{NOTAS}

${ }^{1}$ Em uma tradução livre, Orí é cabeça, contudo não apenas a cabeça física, o Oríodé, mas a parte sagrada e sacralizada nas iniciões, o Orí-inu. É o ponto de ligação com a Ancestralidade, mítica e histórica, bem como portador da individualidade. Na morte do iniciado é apenas seu Orí quem lhe acompanha.

2 O Sopapo Poético surgiu em 2012 atrelado à necessidade de circulação dos poemas dos artistas e militantes do movimento negro do Rio Grande do Sul e desde então se reúnem mensalmente. O nome do grupo, Sopapo, origina-se no tambor produzido nas charqueadas com couro de cavalo, depois modificado e introduzido no carnaval gaúcho. Em 2016 lançam a antologia poética Pretessência.

${ }^{3}$ Contam que Obá, intuída por Oxum, cozinha uma amalá (comida favorita de Xangô) com uma de suas orelhas, fato que causa repulsa ao Orixá que expulsa suas esposas, inclusive Oyá, de seu reino.

\section{REFERÊNCIAS}

CORRÊA, Norton. O Batuque do Rio Grande do Sul: Antropologia de uma religião afro-rio-grandense. $3^{\text {a }}$ Ed. São Luis: Cultura \& Arte, 2016.

EVARISTO, Conceição. Maria Helena Vargas. In: DUARTE, Eduardo de Assis. (org). Literatura e afrodescendência no Brasil: Antologia crítica. V.1. Belo Horizonte: Ed. UFMG, 2011.

FERREIRA, Paulo Tadeu Barbosa. Quem é o orixá Xangô Kamucá na Nação Religiosa de Cabinda? Porto Alegre: Toquí, 2008.

FLORES, Moacyr. Negros na revolução farroupilha: Traição em Porongos e farsa em Ponche Verde. EST Edições, Porto Alegre, 2004.

GILROY, Paul. O Atlântico negro. Trad. Cid Knipel Moreira. São Paulo: Ed. 34; Rio de Janeiro: Universidade Cândido Mendes; Centro de Estudos Afro-asiáticos, 2001.

LEITE, Fábio Rubens da Rocha. A questão ancestral: África negra. São Paulo: Palas Athena: Casa das Áfricas, 2008. 
OXALÁ, Babalorixá Branco de. Efan-deí: O livro dos batuqueiros.

Viamão: [s.n], 2017.

OXALÁ, Pai Ronei de. Africanismo: Culto sem segredo. São Paulo: Biblioteca 24X7, 2009.

SANTIAGO, Ana Rita. Vozes literárias de escritoras negras. Cruz das Almas: Ed. UFRB, 2012.

SILVA, Paulo Roberto S. da. Batuque: seus encantos e rituais. Porto Alegre: BesouroBox, 2016.

SILVEIRA, Maria Helena Vargas da. O jogo de búzio. In: Odara: Fantasia e realidade. Porto Alegre: [s.n], 1993. p. 31-36.

Tia Bernarda de Ogum. In: 1997. p. 41-42.

Tipuana. Porto Alegre: [s.n.],

Recebido: 30 abr. 2020

Aprovado: 09 set. 2020

DOI: 10.3895/rl.v22n38.12821

Como citar: QUADROS, Dênis Moura de. O Batuque do Rio Grande do Sul representado em dois contos, de Maria Helena Vargas da Silveira. R. Letras, Curitiba, v. 22, n. 38 p. 68-82, set. 2020. Disponível em: $<$ https://periodicos.utfpr.edu.br/rl>. Acesso em: XXX.

Direito autoral: Este artigo está licenciado sob os termos da Licença Creative Commons-Atribuição 4.0 Internacional. 